\title{
O ENTENDIMENTO DA FRAGILIDADE AMBIENTAL DO MUNICÍPIO DE GUAÍRA - PARANÁ
}

\author{
Karoline Bueno \\ Professora da SEED/PR e mestre em Geografia pela UNIOESTE - Marechal Cândido Rondon, PR, Brasil \\ karol.bueno89@gmail.com \\ Jozé Edézio da Cunha
Professor doutor e orientador pela UNIOESTE - Marechal Cândido Rondon, PR, Brasil \\ edeziocunha@hotmail.com \\ Leandro Neri Bortoluzzi \\ Professor da SEED/PR e doutorando em Geografia pela FCT/UNESP - Presidente Prudente, SP, Brasil \\ bortoluzzi@ @hotmail.com
}

\begin{abstract}
RESUMO
O presente artigo buscou entender a dinâmica da paisagem do município de Guaíra (PR) e do reconhecimento de suas fragilidades ambientais. Isso se faz relevante a partir da realidade do quadro natural do município que se estende por uma área de contato e transição entre rochas basálticas e areníticas. Para a elaboração desta pesquisa foi adotada uma proposta metodológica que consiste na utilização do conceito de Unidades Ecodinâmicas de Instabilidade Potencial e de Instabilidade Emergente. Para buscar o entendimento das fragilidades foi necessário o mapeamento de características do município de Guaíra, levando em conta os atributos naturais e o uso da terra. O cruzamento das cartas temáticas com as informações básicas resultaram em duas cartas síntese que representam as delimitações das áreas de fragilidade potencial e emergente do município. Dentre as conclusões, destaca-se a confirmação da fragilidade potencial inerente às áreas de rochas sedimentares, juntamente com os solos oriundos dessas, configurando-se em maior grau de fragilidade. Sobre às fragilidades emergentes, constatou-se que evidenciam incoerências no uso da terra que determinam, em porções de ambas as litologias, caráter de maior instabilidade, tendo como determinantes na fragilidade conferida outras variáveis, como solo e relevo, combinados com as práticas agrícolas de monocultivo temporário.
\end{abstract}

Palavras-chave: Paisagem. Mapeamento. Município. Análise integrada.

\section{THE LANDSCAPE AND ENVIRONMENTAL WEAKNESS OF THE MUNICIPALITY OF GUAÍRA - PARANÁ}

\begin{abstract}
The present article sought to understand the dynamics of the landscape of the municipality of Guaíra (PR) and the recognition of its environmental fragilities. This becomes relevant from the reality of the natural picture of the municipality that extends through an area of contact and transition between basaltic and arenite rocks. For the elaboration of this research it was adopted a methodological proposal that consists in the use of the concept of Ecodynamic Units of Potential Instability and Emergent Instability. In order to understand the fragilities, it was necessary to map the characteristics of the municipality of Guaíra, taking into account natural attributes and land use..The crossing of the thematic charts with the basic information resulted in two summary letters that represent the delimitations of the areas of potential and emerging fragility of the municipality. Among the conclusions, we highlight the confirmation of the potential fragility inherent to the sedimentary rocks, together with the soils originating from these, forming a greater degree of fragility. On the emerging fragilities, it was found that they show inconsistencies in land use, which determine, in portions of both lithologies, more instability, with other variables, such as soil and relief, combined with the agricultural practices of temporary cultivation.
\end{abstract}

Keywords: Landscape. Mapping. County. Integrated analysis. 


\section{INTRODUÇÃO}

O conhecimento da paisagem de modo integrado é essencial para o entendimento da interação dos distintos elementos naturais integrantes e formadores do espaço geográfico, objeto este, da Geografia. São cada vez mais perceptíveis as alterações da sociedade no meio, isso ganha consistência com o desenvolvimento de técnicas mais avançadas, bem como o exponencial crescimento da população e o consumo exacerbado derivado do modo de produção capitalista.

Com toda essa transformação, se faz cada vez mais importante: levantar dados, refletir sobre as informações, planejar e agir no meio ambiente, de modo que os impactos negativos sejam ao menos minimizados, garantindo a ocupação humana na forma de um desenrolar histórico que priorize o bem estar socioambiental.

Partindo do que fora introduzido até aqui, evidenciamos neste artigo a aplicação de um método de análise integrada da paisagem - o geossistema - tendo como escala a área do município, que resulta de uma dissertação de mestrado (BUENO, 2015) realizada ao longo do triênio 2013/2014/2015 e que no atual artigo passa sobre uma (re)avaliação de sua aplicabilidade.

A área de estudo esmiuçada é o município de Guaíra, localizado na mesorregião Oeste do estado do Paraná, na fronteira com o Paraguai e na divisa com o estado do Mato Grosso do Sul. Guaíra foi escolhida para ser objeto de estudo porque evidencia uma peculiaridade, que é ser uma área de contato entre duas litologias distintas, o Basalto e o Arenito Caiuá. Sendo assim, o objetivo do estudo foi identificar e representar cartograficamente as áreas suscetíveis à degradação e apresenta como hipótese que ao longo do município onde ocorre o afloramento das rochas areníticas, o ambiente é potencialmente mais frágil que nas áreas de afloramento basáltico, favorecendo a existência de maiores graus de fragilidade emergente.

\section{MATERIAIS E MÉTODOS}

A realização do trabalho se deu em quatro etapas, a primeira diz respeito ao levantamento bibliográfico da temática e uma revisão teórico-conceitual sobre o assunto. O passo seguinte foi o levantamento de dados sobre a área de estudo e elaboração do material cartográfico - as cartas temáticas. A terceira etapa condiz ao aferimento dos dados sistematizados nas cartas para análise e comparação junto a área de estudo. E, a quarta e última etapa se deu pela elaboração das cartas de fragilidade potencial e emergente e análise dos resultados.

A geração das cartas temáticas básicas serve, além de tudo, para subsidiar a avaliação das fragilidades ambientais. Essas cartas também podem ser chamadas de produtos intermediários e são imprescindíveis para a etapa de sobreposição cartográfica que resultou nas cartas finais de síntese com o mapeamento das áreas de fragilidade potencial e emergente de Guaíra-PR.

Entre os levantamentos, tratamentos e elaboração destas cartas temáticas, estabeleceram-se 3 (três) atributos para o estudo dos aspectos do quadro natural/físico da paisagem e 1 (um) atributo que analisa de forma conjunta o quadro socioeconômico do município (Figura 1). Para auxiliar no entendimento das informações, se deu a elaboração de uma carta hipsométrica de Guaíra, que não foi utilizada na sobreposição, mas foi fonte auxiliadora de dados.

Figura 1: Atributos considerados na elaboração das cartas base.

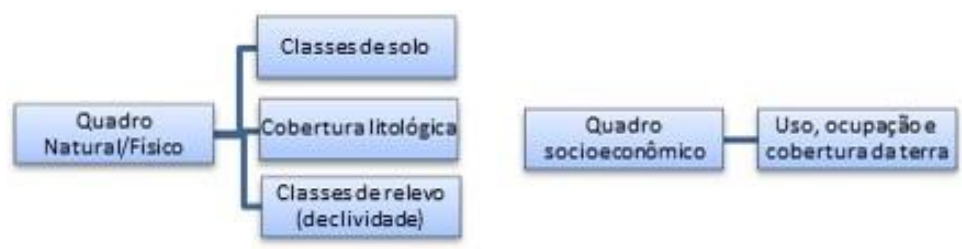

Fonte: Autores 
Os produtos cartográficos foram todos elaborados com o software de código livre QGIS 2.2. Valmiera, onde as cartas sínteses foram geradas a partir da relação das informações e dados obtidos no levantamento bibliográfico, no mapeamento dos aspectos socioambientais do município e por meio de sobreposição cartográfica das cartas intermediárias.

Para a realização das cartas de fragilidade potencial e emergente foram utilizados os preceitos teórico-metodológicos de Ross $(1994 ; 2012)$. Entretanto, foram realizadas algumas adaptações, do mesmo modo que o referido autor fez adaptações quando da implementação de sua metodologia, baseada na proposta de Tricart (1977). Entre as adaptações efetuadas, estão o fato de não ser utilizado neste estudo as variáveis: tipo de cobertura vegetal, gradiente topográfico, detalhamento dos segmentos de vertentes e tipo do modelado.

Para a determinação das áreas de Instabilidade Potencial foram levadas em consideração as informações referentes às variáveis do meio - litologia, relevo e solos - sendo cada uma classificada em grau condizente ao ambiente observado. Já para o entendimento das áreas de instabilidade Emergente, a variável essencial é o uso da terra, a qual em suas diferentes formas interferem distintamente na fragilidade da paisagem. No quadro 1 são elencados os graus de fragilidade conforme os atributos do meio.

Quadro 1: Variáveis do meio físico e graus de fragilidade para a Instabilidade Potencial

\begin{tabular}{|c|c|c|c|}
\hline \multirow{2}{*}{$\begin{array}{c}\text { Instabilidade } \\
\text { Potencial } \\
\text { (Graus de Fragilidade) }\end{array}$} & \multicolumn{3}{|c|}{ Variáveis do Quadro Natural/Meio Físico } \\
\hline & $\begin{array}{c}\text { Relevo (Classes - } \\
\text { Declividade) }\end{array}$ & Litologia & Solos \\
\hline Forte (3) & Acima de $20 \%$ & $\begin{array}{c}\text { Sedimentos } \\
\text { Inconsolidados }\end{array}$ & $\begin{array}{c}\text { Organossolos; } \\
\text { Gleissolos Háplicos }\end{array}$ \\
\hline Média (2) & Entre 8 e $20 \%$ & Arenito & $\begin{array}{l}\text { Argissolos Vermelhos; } \\
\text { Neossolos Litólicos }\end{array}$ \\
\hline Fraca (1) & Até $8 \%$ & Basalto & $\begin{array}{l}\text { Latossolos Vermelhos; } \\
\text { Nitossolos Vermelhos }\end{array}$ \\
\hline
\end{tabular}

Fonte: Autores

A determinação das manchas com a classificação conforme o grau de instabilidade (fragilidade) potencial (Quadro 2) foi dada pela gradação do menor valor possível, neste caso 3 (três) - que representa a soma de 3 valores com peso 1 -, ou seja, baixo grau de instabilidade, até o maior valor possível de ser alcançado, que neste caso é 9 (nove) - soma de 3 valores com peso 3, ou seja, o mais alto grau de instabilidade/fragilidade. Sendo assim, para a situação deste estudo, teve-se a seguinte condição de somatória das variáveis e respectivos graus de instabilidade assumidos pelos resultados das somas:

Quadro 2: Somatória para classificação da fragilidade potencial

\begin{tabular}{|c|c|}
\hline Resultado da somatória dos graus de fragilidade: & Grau de instabilidade conferido: \\
\hline 3 ou 4 & Fraca \\
\hline 5 a 7 & Média \\
\hline 8 ou 9 & Forte \\
\hline
\end{tabular}

Fonte: Autores

A atribuição dos valores conferidos aos atributos do quadro socioeconômico da paisagem, conforme o grau de fragilidade que conferem ao ambiente são apresentados na sequência no Quadro 3. Feito a discriminação dos valores dados aos diferentes usos da terra, houve a análise para determinação da relação com a Fragilidade Potencial, fazendo uma nova somatória e a partir disso, gerar a carta síntese de Fragilidade Emergente.

$\begin{array}{llllll}\text { Caminhos de Geografia } & \text { Uberlândia - MG } & \text { v. 19, n. } 68 & \text { Dez/2018 } & \text { p. 81-100 } & \text { Página } 83\end{array}$


Quadro 3: Graus de fragilidade do quadro socioeconômico.

\begin{tabular}{|c|c|}
\hline $\begin{array}{c}\text { Instabilidade } \\
\text { Emergente } \\
\text { (Graus de } \\
\text { Fragilidade) }\end{array}$ & Variáveis do Quadro Socioeconômico \\
\cline { 2 - 2 } & Cobertura/Uso e ocupação da terra \\
\hline Forte (1) & $\begin{array}{c}\text { Áreas desmatadas recente/Solo exposto: Agricultura extensiva de ciclo } \\
\text { curto (culturas temporárias) e Urbanização moderada e/ou densa. }\end{array}$ \\
\hline Média (2) & Pastagens; Silvicultura e Culturas de ciclo longo (permanentes). \\
\hline Fraca (3) & Florestas naturais; Matas nativas e vegetação herbácea e/ou arbustiva. \\
\hline
\end{tabular}

Fonte: Autores

Do mesmo modo do que fora mencionado anteriormente, a delimitação das manchas com a classificação conforme o grau de instabilidade (fragilidade) emergente foi dada pela gradação do menor valor possível, que neste caso, foi o valor 2 (dois) - que representa a soma de 2 valores com peso 1 -, ou seja, baixo grau de instabilidade, até o maior valor alcançado, que neste caso foi o valor de 6 (seis) - soma de 2 valores com peso 3, ou seja, o mais alto grau de instabilidade/fragilidade. Sendo assim, para esta situação, teve-se a seguinte condição, como pode ser visualizado no quadro a seguir (Quadro 4) de somatória das variáveis e respectivos graus de instabilidade emergente assumidos pelos resultados das somas:

Quadro 4: Somatória para classificação da fragilidade emergente

\begin{tabular}{|c|c|}
\hline Resultado da somatória das variáveis: & Grau de instabilidade conferido: \\
\hline 2 & Muito Fraca \\
\hline 3 & Fraca \\
\hline 4 & Média \\
\hline 5 & Forte \\
\hline 6 & Muito Forte \\
\hline
\end{tabular}

Fonte: Autores

Com base na elaboração das cartas finais, de Fragilidade Potencial e de Fragilidade Emergente, aliado às referências teóricas, aferição de dados empíricos, foi possível realizar uma análise da paisagem do município de Guaíra - PR de modo integrado, as observações são apresentadas e analisadas nas etapas seguintes do trabalho.

\section{ANÁLISE INTEGRADA DA PAISAGEM: MUNICÍPIO COMO ESCALA}

Por mais que inúmeros cientistas apontem a falta de referenciais teóricos em diversas temáticas, incluindo a Geografia, não há como negar que no último século ocorreu uma vasta produção intelectual, resultando em inúmeras e complexas discussões sobre teorias, métodos e práticas voltadas aos estudos ambientais. Entretanto, isso não significa dizer que o conteúdo já está esgotado e muito menos que toda a produção intelectual existente dá conta de abordar de modo eficiente toda problemática ambiental existente no mundo. É fundamental aprofundar as formas de análise e de aplicabilidade das diversas teorias que buscam entender a paisagem num sentido amplo e integrado.

Com base no conhecimento historicamente acumulado na Geografia, o entendimento do espaço geográfico é feito a partir da utilização das categorias geográficas de análise, como por exemplo: região, território, lugar e paisagem. Cabe ao pesquisador escolher a categoria que lhe auxiliará da melhor forma para analisar o conteúdo de sua pesquisa. Vale salientar ainda, que a conceituação das categorias não é algo imutável, no decorrer do desenrolar da Geografia, evidencia-se novos olhares as categorias. $\mathrm{O}$ conceito de paisagem, por exemplo, foi alterado ao longo do tempo e até mesmo sendo visto de distintas formas conceituais por diferentes pesquisadores em virtude de concepções de mundo diferenciadas.

\begin{tabular}{llllll}
\hline Caminhos de Geografia & Uberlândia - MG & v. 19, n. 68 & Dez/2018 & p. 81-100 & Página 84
\end{tabular}


Carvalho et al. (2002) trazem uma importante contribuição para compreender melhor esta evolução do conceito de paisagem, relatando que a ideia de paisagem foi diferente ao longo das épocas: antiguidade, idade média, renascimento, etc. Se para a sociedade como um todo o entendimento de paisagem se difere, o mesmo acontece na Geografia, ganhando destaque algumas frentes, as escolas Alemã, Francesa e Soviética, cada qual elaborando profícuos debates acerca do entendimento do que é paisagem.

Entre os estudiosos que se debruçaram a entender a paisagem de modo integrado, Bertrand (2004, p. 141) conceituou paisagem como "(...) resultado da combinação dinâmica, portanto instável, de elementos físicos, biológicos e antrópicos que, reagindo dialeticamente uns sobre os outros, fazem da paisagem um conjunto único e indissociável, em perpétua evolução".

Metzger (2001, p. 4), também propôs uma definição integradora de paisagem, concebendo-a como “(...) um mosaico heterogêneo formado por unidades interativas, sendo esta heterogeneidade existente para pelo menos um fator, segundo um observador e numa determinada escala de observação (...)".

Sob o mesmo viés, para Nóbrega e Cunha (2011, p. 64), a base para a definição de paisagem é "(...) uma porção do espaço perceptível, concreta, visível, onde é possível identificar os componentes, sua distribuição e as relações de vizinhança que se estabelecem (...)"; assim, traduzindo-se em "(...) um arranjo de objetos, definidos por formas e por materiais produzidos ao longo de um tempo que é, por sua vez, variável para cada elemento individualmente e para o conjunto (...)".

Como já dito, as concepções de paisagem são inúmeras, na leitura detalhada do entendimento de paisagem pelos estudiosos que se debruçaram sobre esta temática é possível perceber que ocorre um direcionamento aonde o entendimento da paisagem deve levar em consideração os principais elementos naturais/físicos e também os elementos sociais, analisando a sua estrutura e funcionamento. Tudo isso, resulta em complexas inter-relações da entre sociedade e natureza, e a paisagem é o reflexo dessa interação.

Além de tratar da concepção do conceito de paisagem, é necessário também a sistematização de métodos e modelos para se conceber o caráter integrado da paisagem. Pensar e propor formas de se compreender a complexidade das paisagens em uma análise espacial de forma integrada era uma necessidade que, como apontam Carvalho et al. (2002,) já era colocada desde os fins do século XIX, mas que ganhou força e efetivamente se concretizou na década de 1970. Neste contexto surgiu o paradigma geossistêmico, e coube a "(...) Sotchava, [em] 1963, [segundo Carvalho et al. (2002)] o mérito da sistematização deste modelo integrado de análise da paisagem denominando-o GEOSSISTEMA" (p. 332).

Sotchava $(1977$, p. 2) trouxe a ideia de que não se deve reservar o estudo somente aos componentes da natureza, "(...) mas as conexões entre eles; não se deve restringir à morfologia da paisagem e suas subdivisões mas, de preferência, projetar-se para o estudo de sua dinâmica, estrutura funcional, conexões, etc".

Nisso, o conceito de geossistema de Sotchava esteve mais circunscrito ao quadro natural/físico das paisagens, mesmo admitindo certa ligação com outros fatores de outras ordens; tal como pode ser visto no trecho em que o autor estabelece que

\begin{abstract}
Embora os geossistemas sejam fenômenos naturais, todos os fatores econômicos e sociais, influenciando sua estrutura e peculiaridades espaciais, são tomados em consideração durante o seu estudo e suas descrições verbais ou matemáticas. Modelos e gráficos de geossistemas refletem parâmetros econômicos e sociais influenciando as mais importantes conexões dentro do geossistema, sobretudo no que se refere às paisagens grandemente modificadas pelo homem. Influências antropogênicas dizem respeito a numerosos componentes naturais de um geossistema. (...). As ditas paisagens antropogênicas nada mais são do que estados variáveis de primitivos geossistemas naturais, podendo ser referidos à esfera de estudo do problema da dinâmica da paisagem. (SOTCHAVA, 1977, p. 6-7).
\end{abstract}

Mas, apesar "[...] do caráter pioneiro de Sotchava, foi a partir dos trabalhos de Bertrand (1972) que o conceito geossistêmico ganhou mais consistência, atribuindo uma nova interpretação ao conceito de paisagem" (CARVALHO et al., 2002, p. 333). Em suma, a proposta de Bertrand para o geossistema

$\begin{array}{llllll}\text { Caminhos de Geografia } & \text { Uberlândia - MG } & \text { v. 19, n. } 68 & \text { Dez/2018 } & \text { p. 81-100 } & \text { Página } 85\end{array}$


apresentou-se mais ampla e complexa, constituindo "[...] três conjuntos diferentes: o sistema geomorfogenético (potencial ecológico), a dinâmica biológica e sistema de exploração antrópica" (CARVALHO et al., 2002, p. 333).

Ao analisar a vasta produção cientifica que utiliza o conceito de paisagem, nota-se que a grande maioria, utiliza como escala a "bacia hidrográfica". Cunha et al. (2012) esclarece que isso ocorre, pois, a bacia hidrográfica é "(...) uma das maneiras mais eficientes de compreender e monitorar os diferentes níveis de fragilidade potencial e emergente dos ambientes" (p. 216).

No entanto, apesar da utilização das bacias hidrográficas como escala para análise integrada da paisagem se apresentar coerente, ela pode não ser a única escala de análise desta categoria. Pensando do ponto de vista do planejamento e gestão, uma outra escala que aparece como viável, é a utilização do "município", que é a menor unidade administrativa no Brasil, bem como inúmeros outros países. Estudos que utilizam o município como escala ainda são poucos, ainda que cada vez mais frequentes.

Bergamo e Almeida (2006), ao afirmarem que "O planejamento ambiental na escala municipal é uma das muitas alternativas para a preservação, recuperação e conservação dos sistemas ambientais (...)" (p. 1), justificam a importância da escolha desta escala vista a possibilidade do reconhecimento de problemas oriundos do mau uso e ocupação da terra, subsidiando o poder público para tomar medidas de recuperação locais e de medidas que disciplinem o uso e a ocupação da terra e das águas de modo a prevenir possíveis impactos e degradação no futuro, e de forma que tudo isso possa, e deva, envolver além do poder público municipal, também a população local.

Scheibe (1997), enfatiza que por se tratar de uma das unidades administrativas básicas da organização do nosso território, há uma maior proximidade com/dos cidadãos, no sentido da possibilidade da participação mais efetiva destes em pensar o planejamento, o ordenamento e a mitigação de impactos neste território, por isso, se faz extremamente importante firmar essa visão integradora das relações interativas no "geossistema municipal". Esta perspectiva pode corroborar para os estudos necessários na elaboração de planos diretores, que é uma exigência em todos os municípios brasileiros, como foi estabelecido na Lei Federal no $10.257 / 2001$, denominada "Estatuto da Cidade" (BRASIL, 2009).

\section{A PAISAGEM DE GUAÍRA}

Guaíra se localiza no extremo oeste paranaense (Figura 2), que, pela delimitação regional desenvolvida pelo IBGE, situa-se na Mesorregião Oeste do Paraná, geomorfologicamente localizado no Terceiro Planalto Paranaense (MAACK, 2002), na área correspondente à Bacia Hidrográfica do Paraná III - conforme divisão estabelecida pelo Instituto das Águas Paraná (2013) (extinta SUDERHSA). O município margeia o rio Paraná e o reservatório do lago de Itaipu (a oeste, na fronteira do Brasil com o Paraguai e divisa com o estado do Mato Grosso do Sul a norte), no qual a rede hidrográfica deságua, com destaque para os rios Taturí e Zororó. São limites municipais no território paranaense: Terra Roxa (a leste), Mercedes (ao sul) e Altônia (ao norte).

O município possui, segundo o censo 2010 do IBGE, 30.704 habitantes em uma área territorial equivalente a $568,845 \mathrm{~km}^{2}$ (IPARDES, 2013). Guaíra foi historicamente ocupada por populações indígenas e recebeu contingentes populacionais portugueses e espanhóis paralelo à colonização do Brasil. O município foi emancipado no ano de 1951 e por um longo período teve suas atividades econômicas fortemente ligadas ao turismo, principalmente devido à existência das Sete Quedas, um conjunto de quedas d'água (cachoeiras), que tinha considerável valor natural e paisagístico para o município (SOUZA; SILVA, 2007).

Atualmente a agricultura é o setor de maior destaque no município, sendo a soja, o milho, trigo e a mandioca os produtos mais cultivados. Além da agricultura, a pecuária é uma atividade frequente, com destaque para a criação de gado bovino de leite e de corte (SEMA, 2010). Após o represamento do rio Paraná e a formação do lago de Itaipu, as Sete Quedas foram submersas e o setor do turismo deixou de ser uma atividade de grande destaque econômico local. Em de ambas as margens do rio Paraná, seja em Guaíra no Brasil ou do lado paraguaio, ocorreram intensas alterações após a inundação que deu origem ao Lago de Itaipu, ocasionando interferências sociais, físicas e biológicas. 
Figura 2: Localização do município de Guaíra.

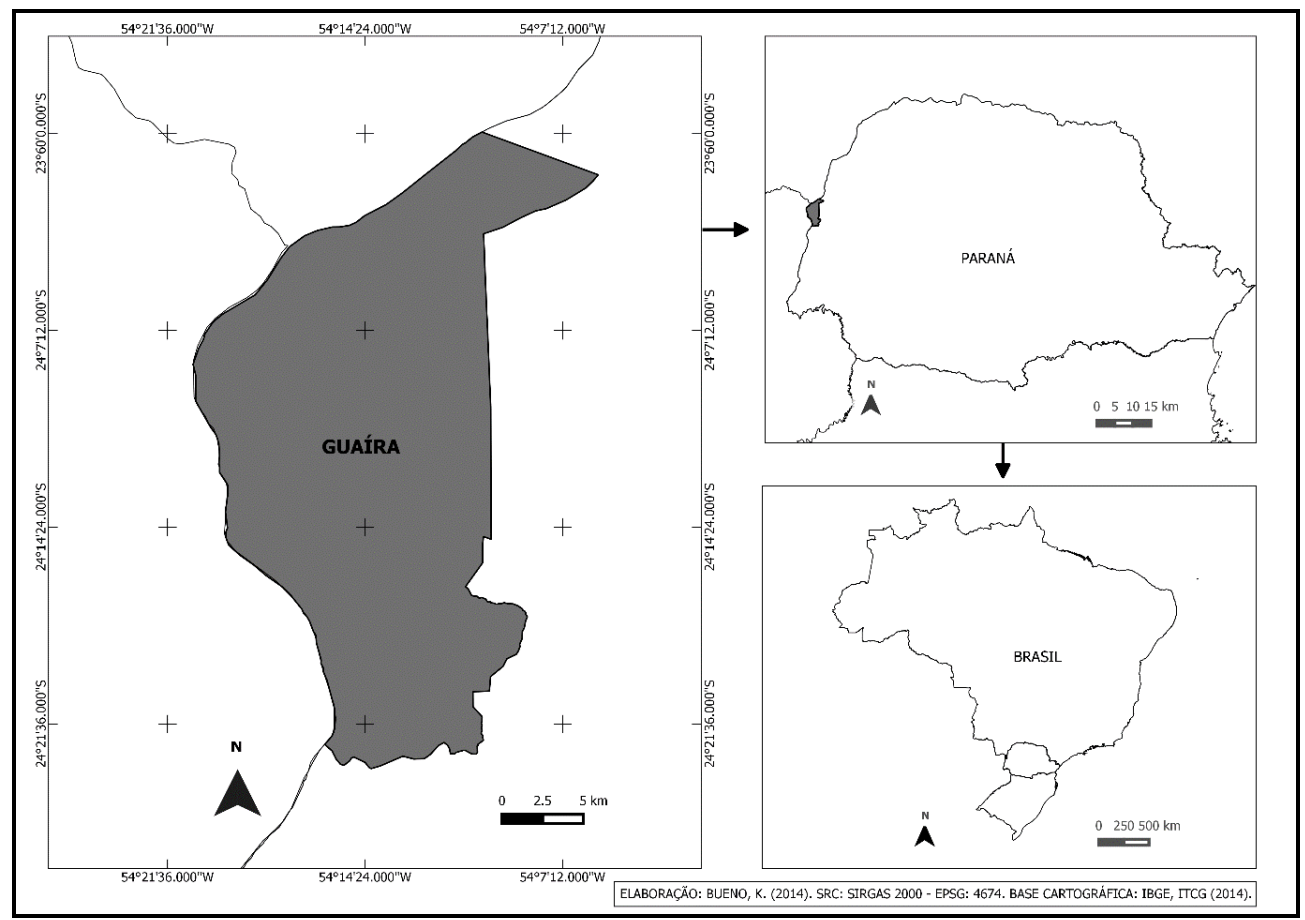

Fonte: Autores

Ao analisar os mapeamentos já existentes sobre o quadro geológico de Guaíra, a grande maioria dos estudos generalizam a distribuição de rochas basálticas por todo o município. Porém, trabalhos como Mineropar (2001; 2006), Bade (2014), Faria e Rickli (s.d.), entre outros, além de observações empíricas, nota-se que o território do município se encontra em uma faixa de transição de litologias ígnea e sedimentar.

A formação ígnea foi configurada a partir de intensos derrames vulcânicos, com predomínio da consolidação de basalto (rocha basáltica) (MAACK, 2002); estes derrames de rochas ígneas são de idade Jurássica-Cretácea e recobrem as rochas sedimentares da Formação Botucatu que recobriam a área até a ocorrência dos eventos de derrame mencionados (MINEROPAR, 2001). A seguir na figura 3, são apresentadas evidências das litologias supracitadas.

Figura 3: Afloramento de Basalto (esquerda) e solos provenientes do Arenito Caiuá (direita).

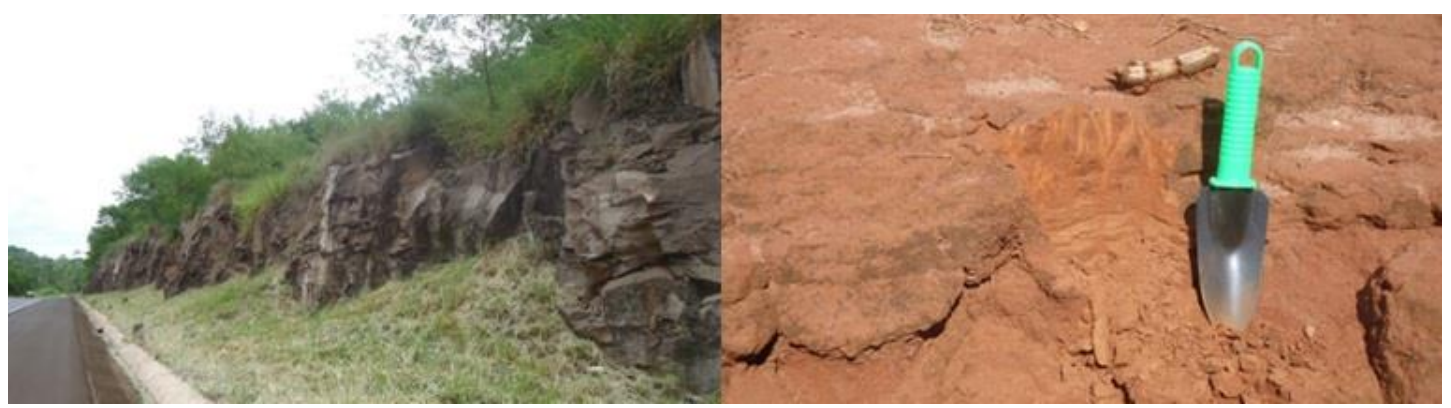

Fonte: Autores

Assim, pode-se afirmar que o município de Guaíra se situa em área de caráter transitório, pois extrapola os limites da Formação Serra Geral, abarcando uma cobertura litológica pertencente ao Grupo Bauru - Formação Caiuá, que “(...) corresponde a arenitos bem selecionados, com estratificação cruzada de médio a grande porte característica (...) [de coloração] marrom-avermelhado a arroxeado, finos a médios, quartzosos (...)" (MINEROPAR, 2001, p. 167).

$\begin{array}{llllll}\text { Caminhos de Geografia } & \text { Uberlândia - MG } & \text { v. 19, n. 68 } & \text { Dez/2018 } & \text { p. 81-100 } & \text { Página }\end{array}$


Com base em levantamentos empíricos e toda literatura analisada entende-se especificamente que o município de Guaíra abrange uma zona de contato e transitória para a Formação Caiuá, mesmo que predominando as rochas basálticas. Em inúmeros estudos, a exemplo: Fonseca e Czuy (2005), Nóbrega e Serra (2009), Gonçalves Junior (2010) e Bade (2014), sinaliza-se que em áreas de contato entre o basalto da Formação Serra Geral e o arenito da Formação Caiuá, são atribuídas particularidades relacionadas aos solos, bem como o uso e ocupação destes.

Nas figuras a seguir (Figuras 4 a 8) são apresentados os mapas com os atributos naturais e os solos que cobrem a área (conforme mapeamento da EMBRAPA realizado em 1981 (atualizado em EMBRAPA, 2013) - e disponibilizado em meio cartográfico pelo ITCG, 2013) e a carta de uso da terra, para compreensão da dinâmica socioeconômica relacionadas com as potencialidades naturais da área de estudo.

Figura 4: Carta de litologia do município de Guaíra.

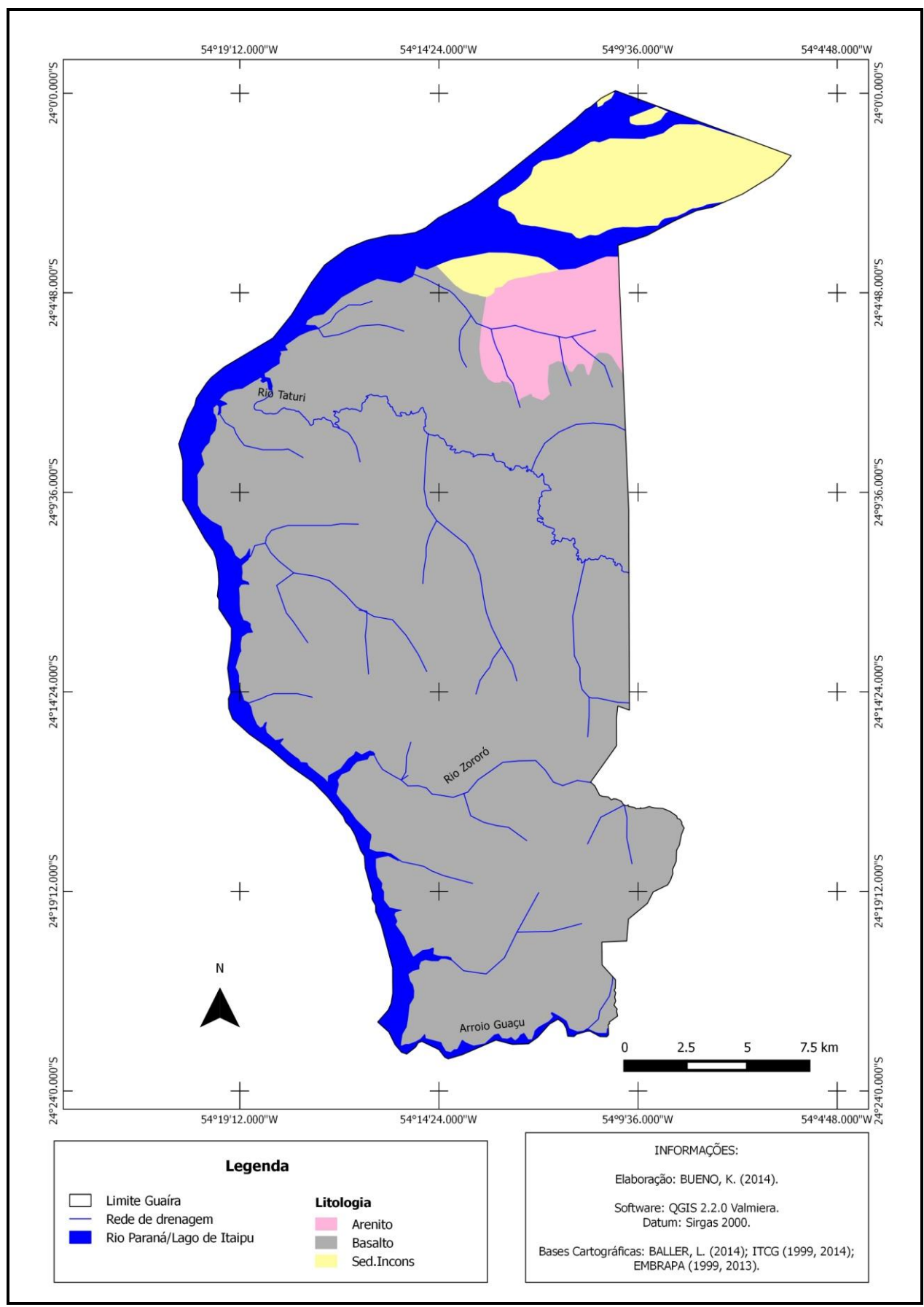

Fonte: Autores 
Figura 5: Carta de solos do município de Guaíra.

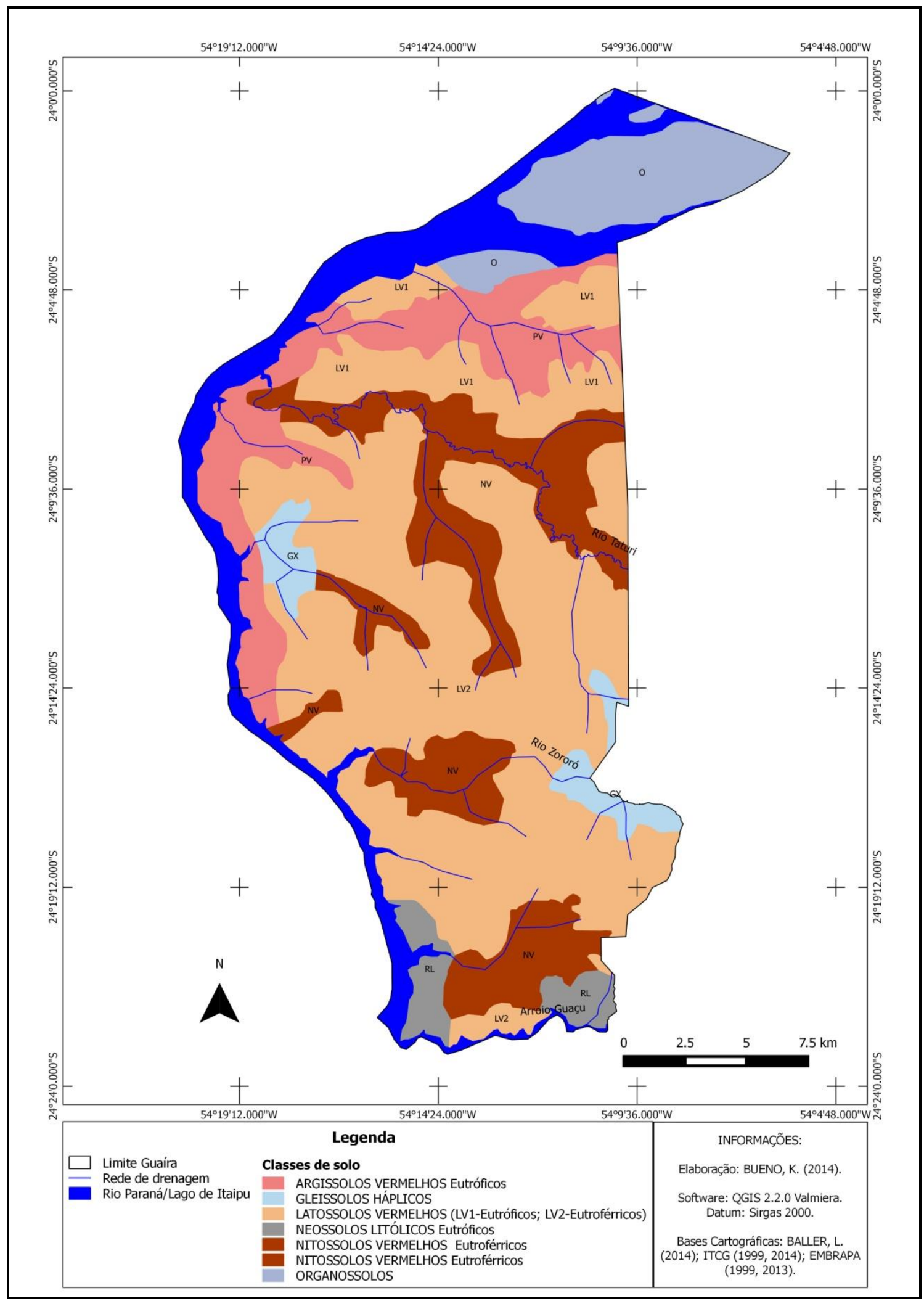

Fonte: Autores 
Figura 6: Carta de declividade do município de Guaíra.

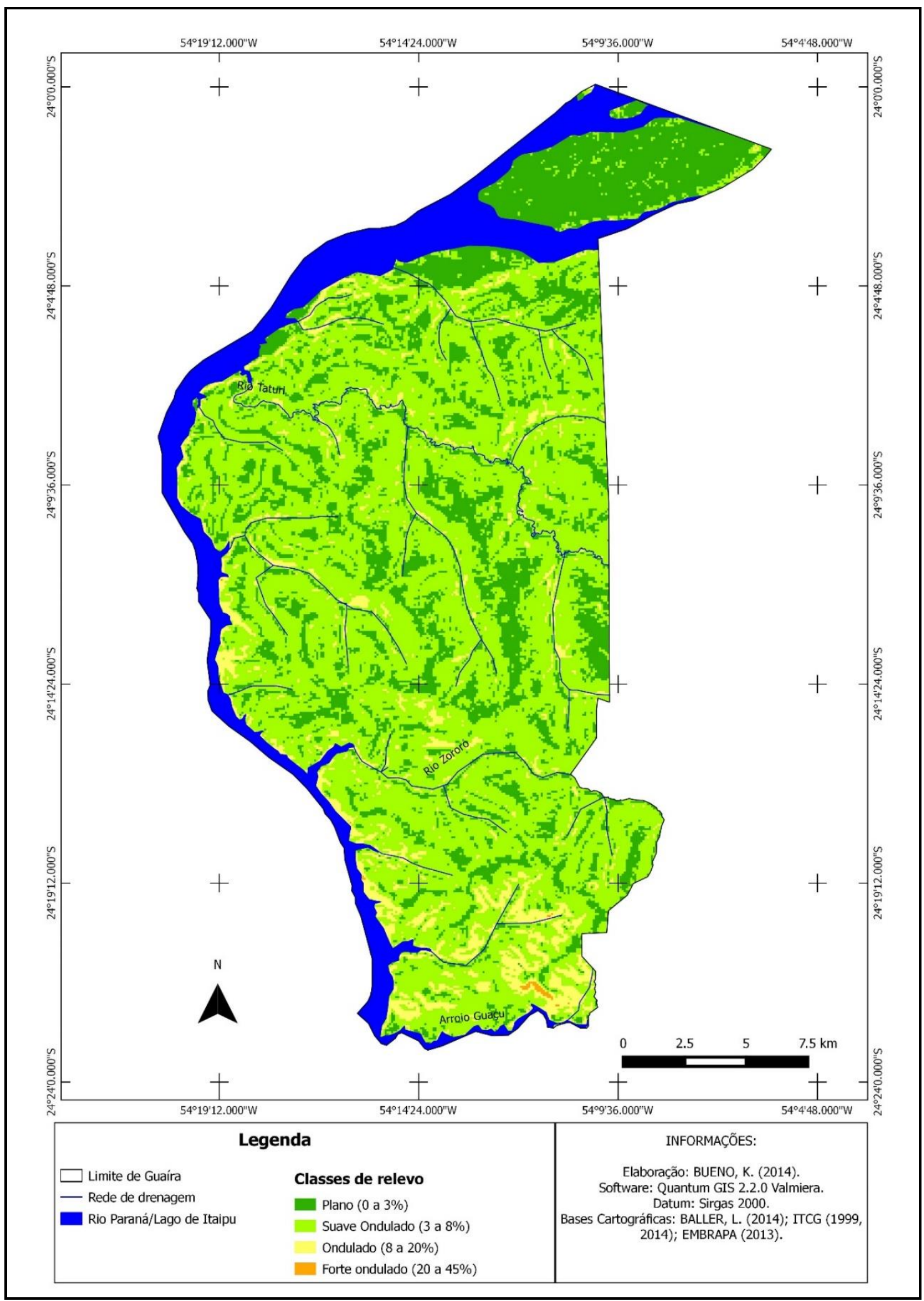

Fonte: Autores 
Figura 7: Carta de hipsometria do município de Guaíra.

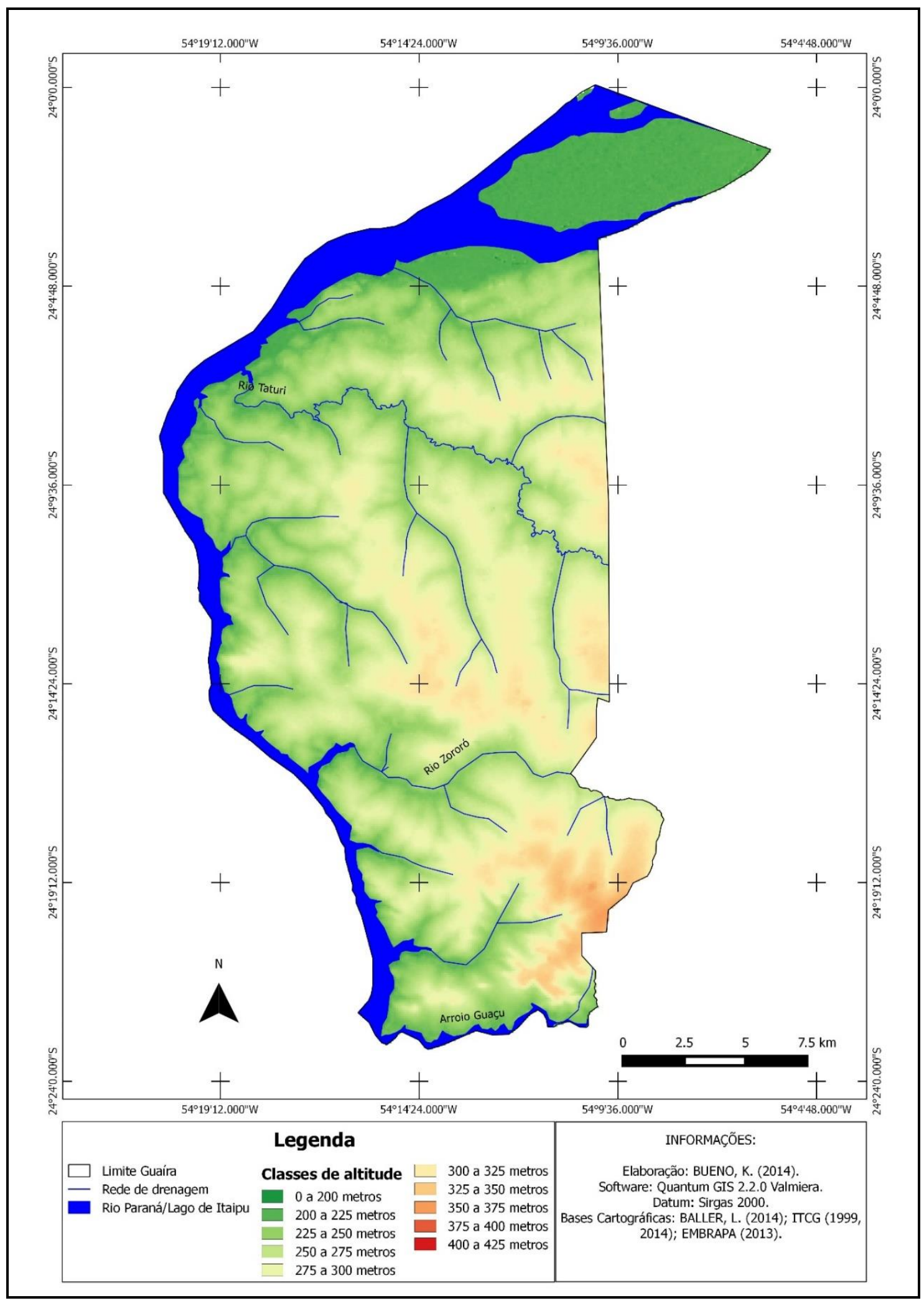

Fonte: Autores 
Figura 8: Carta de uso da terra do município de Guaíra.

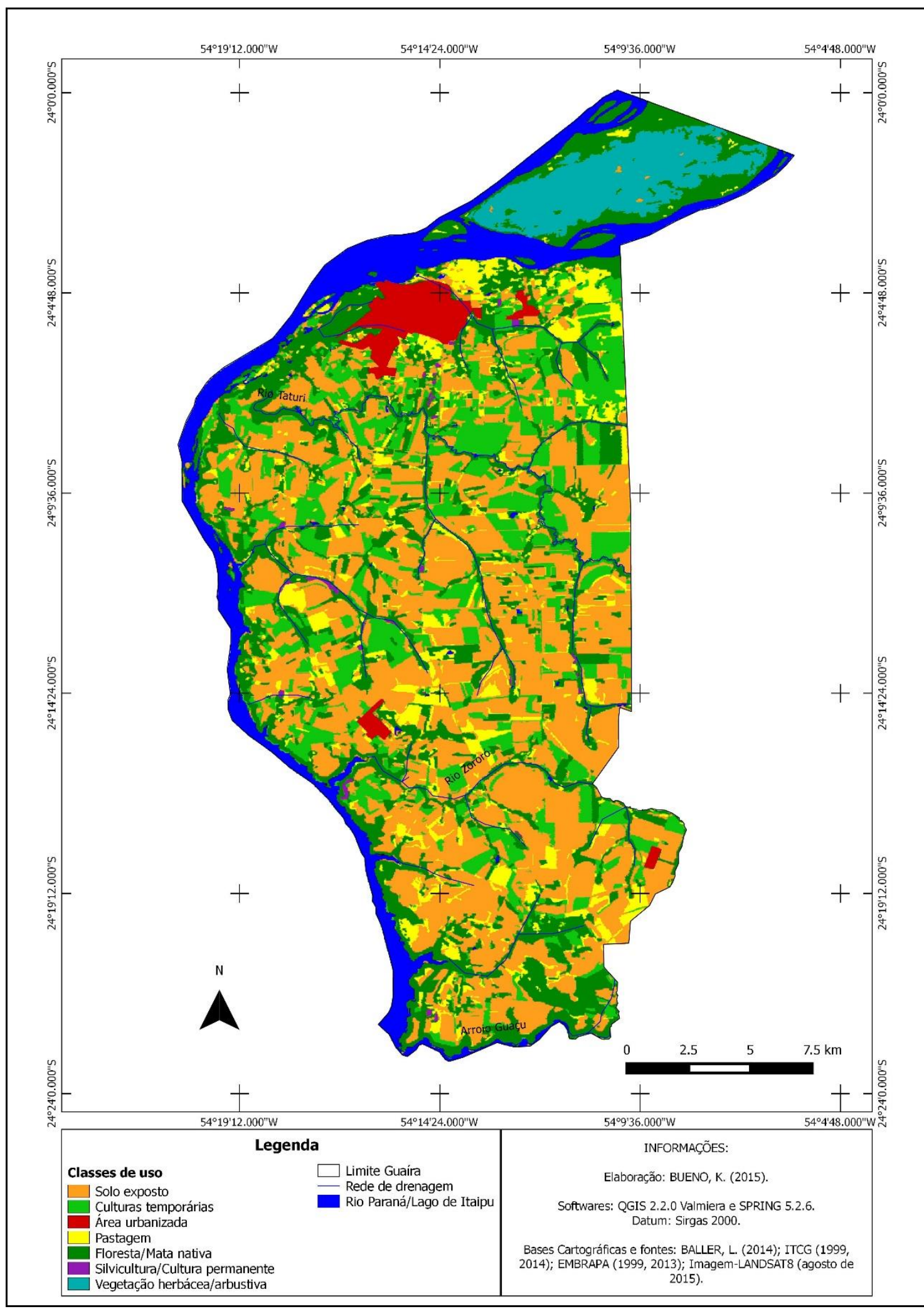

Fonte: Autores 
Fica evidente a tendência e/ou padrão na distribuição dos solos na orientação da vertente, que pode ser sintetizada da seguinte forma: na área basáltica, os latossolos se encontram nos topos e alto das vertentes, enquanto os nitossolos se encaixam nas porções de média a baixa vertente. Na porção onde ocorre a transição para o arenito, o padrão é de presença de latossolos na alta e média vertente, já nas porções de média a baixa vertente predominam os argissolos. Na área sul de Guaíra ocorrem situações mais especificas, com manchas de neossolos de origem litológica basáltica. Por fim, na área nordeste do município, onde localiza-se uma grande ilha fluvial no rio Paraná, ocorrem organossolos e sedimentos inconsolidados.

O relevo é caracterizado por níveis baixos de declividade, em grande parte plano a suave ondulado. As áreas mais dissecadas, ou seja, com gradiente de declividade maior, ocorrem ao sul e sudeste, já as mais planas ao norte e noroeste de Guaíra. As altitudes variam entre 200 e 375 metros acima do nível do mar.

Em uma leitura da (inter)relação entre as variáveis "relevo x solo x geologia", é possível observar que, os solos mais profundos, menos friáveis, mais desenvolvidos, com maior concentração de ferro, distribuem-se em porções de relevo com índices de dissecação de maior amplitude, e que assentamse na área coberta por geologia de origem ígnea. Os solos menos desenvolvidos, mais friáveis e com menor concentração de ferro, sobrepõem uma geologia arenítica que configura-se em relação direta com um relevo de menor dissecação. Isso evidencia que um elemento condiciona o outro, ora um sendo mais determinante que outro, mas nunca deixando de estarem em estreita relação e interação, tanto na sua gênese quanto em suas constantes transformações.

Guaíra apresenta homogeneidade em relação ao clima, definido pelo IAPAR (1994) como Cfa (classificação climática de Koppen), ou seja, uma localidade com clima subtropical mesotérmico de verões quentes, geadas pouco frequentes, maior volume de precipitação no verão e sem estação seca definida. A temperatura média anual fica entre $22^{\circ}$ e $23^{\circ}$ Celsius e com precipitação de 1400 a $1600 \mathrm{~mm}$ anuais. Devido a homogeneidade, o clima atua de forma equivalente ao logo de toda área do município.

\section{A RELAÇÃO ENTRE NATUREZA E AS ATIVIDADES ECONÔMICAS}

O local onde se situa Guaíra, bem como os municípios vizinhos em ambas as margens do rio Paraná (Brasil e Paraguai), foram tomados por portugueses e espanhóis em período paralelo a colonização do Brasil. Mas é fundamental mencionar que esta área já era anteriormente ocupada por uma expressiva população indígena da etnia Guarani (SOUZA; SILVA, 2007).

As transformações na paisagem de maior impacto começaram a ocorrer a partir de 1902, quando se estabeleceu no local a empresa Mate Laranjeira, que deu início às chamadas obrages nesse território. Pouco tempo depois, a partir de um decreto do governo estadual, a área se emancipou e passou a constituir-se como município e recebeu o nome de Guaíra. As obrages tinham por característica extrair erva-mate e madeira e se utilizavam de mão-de-obra de trabalhadores do país vizinho - paraguaios, que eram denominados mensus. Essa produção era escoada pelo rio Paraná e Estuário da Prata e seguiam, principalmente, para a Argentina e para Inglaterra (GREGORY, 2002). Isso se dá no contexto da "marcha para o oeste". Neste mesmo compasso, o governo do Paraná, com receio de ter terras perdidas para esse possível novo território, se comprometeu a estimular a ocupação feita exclusivamente por brasileiros nesta área do oeste paranaense, que até este momento era bem pouco habitada.

O modelo de ocupação dessa região se deu pela atuação de companhias de colonização que buscaram majoritariamente incentivar a ocupação da região com povos vindos dos estados de Santa Catarina e Rio Grande do Sul. Os migrantes que em Guaíra se fixavam, praticavam predominantemente atividades agrícolas, intensificando-se ainda mais no período atual, acompanhando a forte tendência de propagação de cultivos de grãos voltados ao mercado de exportação, cultivados de forma intensiva por grande parte da mesorregião oeste do Paraná.

A expressividade do setor agropecuário evidencia-se ao constatar a existência de aproximadamente 1.200 estabelecimentos rurais conforme dados do último censo agropecuário realizado no país, que apresenta dados referentes ao ano de 2006 (IPARDES, 2013). O enfoque dado para as distintas atividades deste setor é melhor exemplificado no quadro a seguir (Quadro 5). 
Quadro 5: Estabelecimentos rurais de Guaíra conforme atividade desenvolvida.

\begin{tabular}{|c|c|c|}
\hline Atividade econômica & No de estabelecimentos & Área (ha) \\
\hline Lavoura temporária & 863 & 31.510 \\
\hline Horticultura e floricultura & 29 & 150 \\
\hline Lavoura permanente & 7 & 18 \\
\hline $\begin{array}{c}\text { Produção de sementes, mudas e outras } \\
\text { formas de propagação vegetal }\end{array}$ & 1 & $\mathrm{X}$ \\
\hline Pecuária e criação de outros animais & 271 & 3887 \\
\hline Produção florestal de florestas plantadas & 3 & 10 \\
\hline Produção florestal de florestas nativas & 2 & $\mathrm{X}$ \\
\hline Pesca & 18 & 35 \\
\hline Aquicultura & 2 & $\mathrm{X}$ \\
\hline Total & $\mathbf{1 . 1 9 6}$ & $\mathbf{3 5 . 7 8 8}$ \\
\hline
\end{tabular}

Fonte: Autores

A configuração natural em Guaíra, com áreas compostas de solos profundos, bem drenados, ricos em ferro e assentados sobre relevo sem fortes amplitudes topográficas, são favoráveis à agricultura em lavoura temporária (Figura 9) e facilitam essas práticas agrícolas a ocorrerem de maneira bastante eficiente. $\mathrm{Na}$ área de transição para o arenito predomina a prática da pecuária, isso se relaciona aos tipos de solos, mais arenosos e friáveis, com menor potencial para a agricultura, devido a menor fertilidade e uma maior fragilidade no que tange aos processos erosivos.

Figura 9: Área de cultivo monocultor em latossolo (Guaíra-PR).

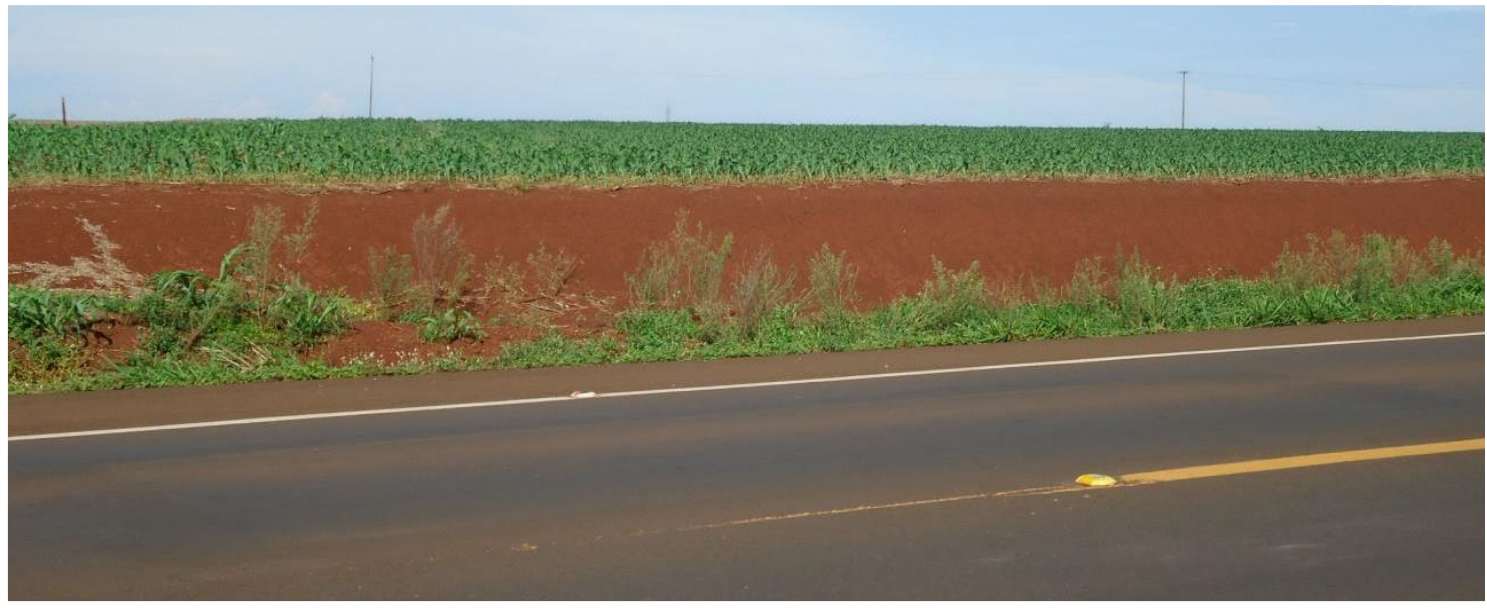

Fonte: Autores

Outras atividades destacaram-se concomitantemente às atividades agrícolas, em especial o extrativismo vegetal, a pecuária (Figura 10), a mineração (Figura 11) e o turismo, devido a existência das famosas e exuberantes "Sete Quedas". Este conjunto de quedas d'água naturais era um dos pontos turísticos de maior destaque na região, e que foi extremamente importante na dinamização econômica de Guaíra, pois gerava um fluxo contínuo de pessoas - visitantes brasileiros e estrangeiros - e consequentemente, aumentava a circulação de capital no município. Porém, devido a formação do Lago de Itaipu após a construção da barragem da usina hidrelétrica, esta formação natural acabou ficando submersa, e a partir de então, esse setor da atividade econômica de Guaíra foi sendo deixado um pouco de lado, dando espaço para a ascensão de outras atividades (SOUZA; SILVA, 2007, p. 86). 
Figura 10: Pecuária em área de sedimentos inconsolidados

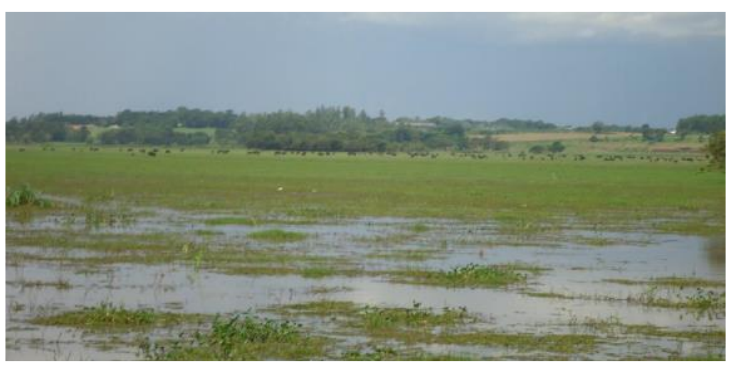

Fonte: Autores
Figura 11: Depósito de areia extraído no leito do Rio Paraná

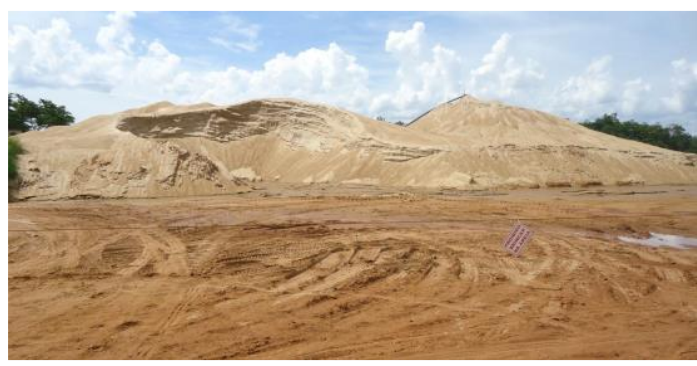

Fonte: Autores

A respeito da mineração, a extração de areia é a atividade mais expressiva para o município, sendo decorrente da dragagem no leito do rio Paraná. Apesar de não existirem muitas empresas no setor, a quantidade produzida de areia em metros cúbicos no município é muito significativa, $265.266 \mathrm{~m} 3 / a n$. Também ocorre extração de argila e produção de pedra brita a partir da litologia basáltica.

\section{FRAGILIDADE POTENCIAL E EMERGENTE DE GUAÍRA}

Concluído as cartas de atributos naturais de Guaíra, quantificação dos graus de instabilidade para cada variável a partir da fragilidade que cada um infere ao ambiente, seguindo a proposta metodológica de Ross (1994; 2012), foi gerada a carta de fragilidade potencial (Figura 12).

Ao analisar este produto cartográfico, não é possível estabelecer um padrão para toda a área sobre a relação entre posição na vertente e grau de fragilidade, ou seja, conforme os setores de alta, baixa ou média vertente.

$\mathrm{Na}$ área onde encontra-se a cobertura basáltica e predominam solos mais profundos e bem drenados predominou o nível de fragilidade potencial fraca. A ocorrência de áreas com graus médios relacionam-se com os locais onde a declividade do terreno é mais acentuada, e ainda a presença de grau de fragilidade mais acentuado em áreas de maior altimetria. Os graus de fragilidade médios, também estão relacionados às áreas de ocorrência de duas classes de solos: os neossolos litólicos e os gleissolos háplicos. Solos estes, que são menos desenvolvidos e conferem ao ambiente uma propensão maior de instabilidade.

Os locais com maior nível de fragilidade/instabilidade correspondem à faixa de transição do basalto para a cobertura litológica do Arenito Cauiá. Nessa área ocorre uma estreita relação entre três variáveis: uma geologia menos estável - (Arenito) e solos com instabilidade média (Argissolos) distribuídos em pontos mais específicos do relevo (média a baixa vertente), conferindo assim um nível de fragilidade potencial considerado médio.

$\mathrm{Na}$ porção localizada no extremo noroeste do município, onde existem ilhas fluviais de cobertura litológica de sedimentos inconsolidados e presença de organossolos, tem-se uma situação que pode ser considerada mais frágil, com fragilidade potencial forte. Resultado da relação existente entre solo e geologia. 
Figura 12: Carta de fragilidade potencial do município de Guaíra.

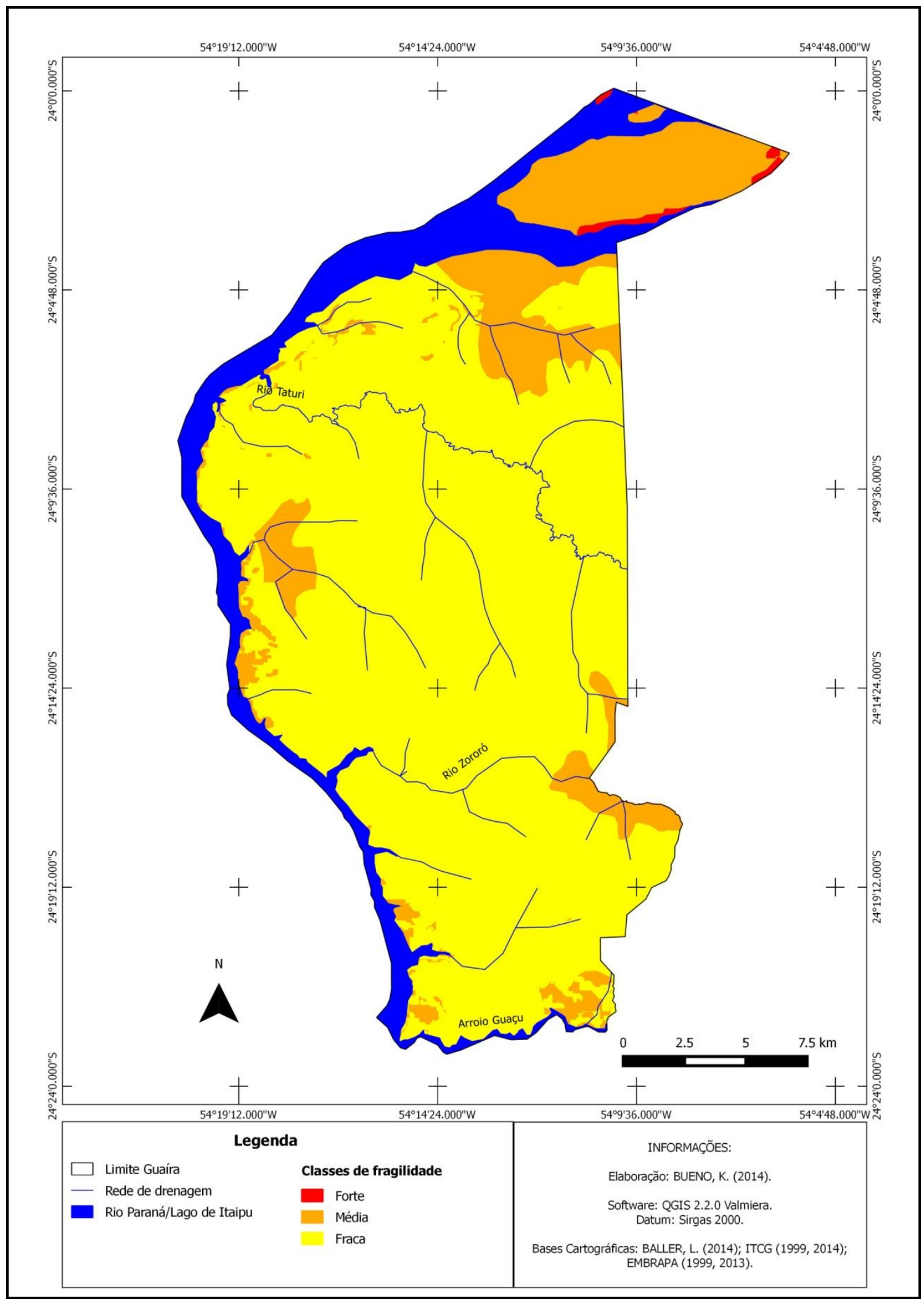

Fonte: Autores 
A carta a seguir (Figura 13) é resultante da carta de fragilidade potencial com a carta de uso da terra, e sintetiza as áreas em que o uso da terra potencializa a fragilidade natural do ambiente.

Figura 13: Carta de fragilidade emergente do município de Guaíra.

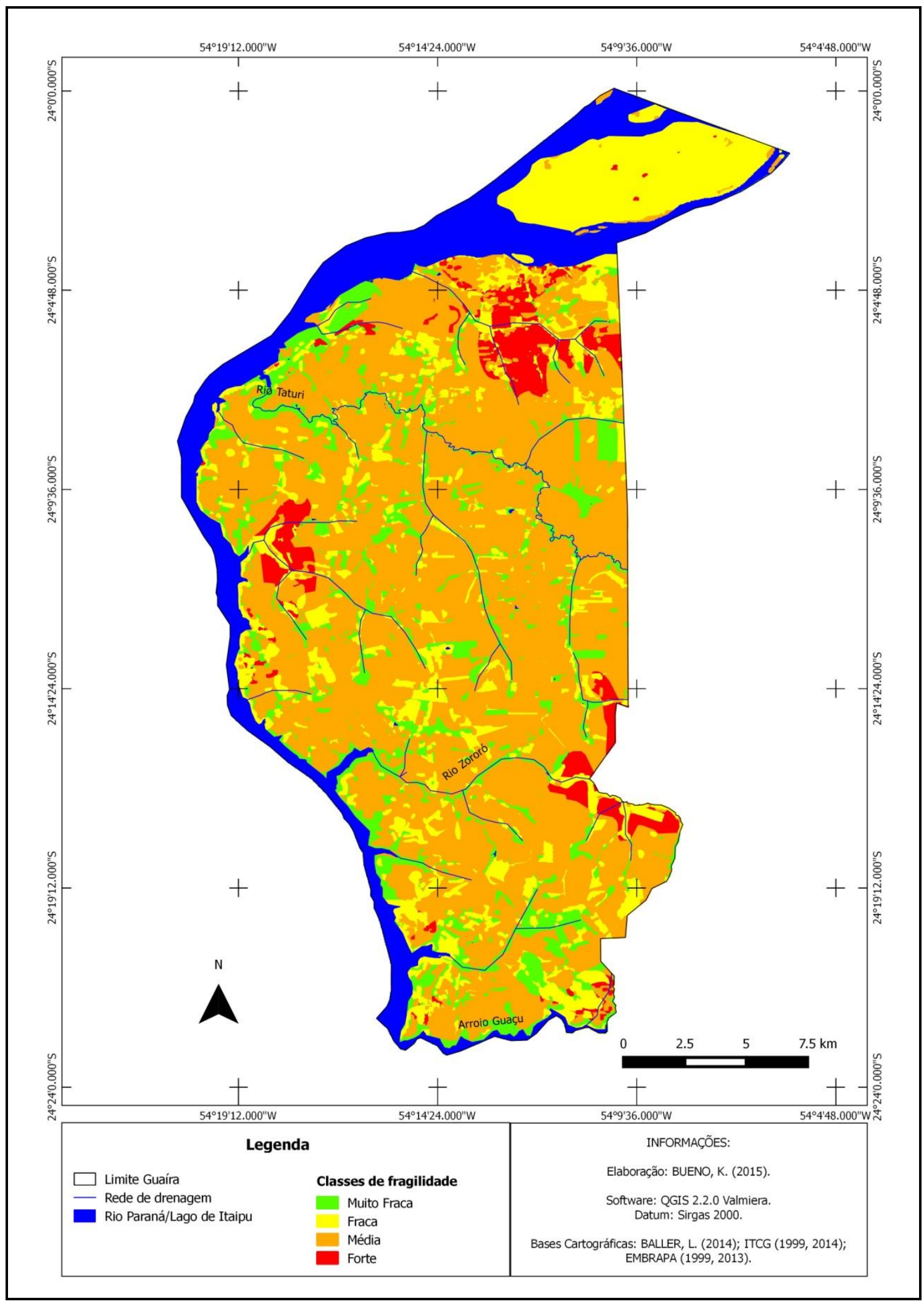

Fonte: Autores 
O ordenamento do uso e ocupação da terra em Guaíra apresentara quatro níveis conforme a incompatibilidade do uso e ocupação em relação à fragilidade potencial (do quadro natural), indo de muito fraca, fraca, média até forte.

As áreas com fragilidade emergente fraca são preponderantemente cobertas por vegetação nativa elemento este da paisagem natural que traz maior estabilidade ao ambiente. Os setores com fragilidade emergente fraca não apresentaram um padrão ou tendência muito específicos, tratando-se de áreas em que o uso e ocupação é compatível com as potencialidades e fragilidades naturais conferidas a estas áreas. Aproximadamente $70 \%$ da área total do município foi classificada com o nível médio de fragilidade emergente. Esse nível conferido a estas áreas está relacionado à utilização da terra para as culturas temporárias, que são majoritárias na área rural do município. Em áreas urbanizadas (sede do município e áreas de distritos municipais) não ocorrem fragilidades mais acentuadas, devido aos fatores do quadro natural que conferem uma estabilidade maior a este ambiente não deixando-o tão suscetível aos desequilíbrios ambientais. Por fim, nos setores com fragilidade emergente considerada forte é possível observar dois padrões específicos com situações e condições para essa configuração, são elas:

Situação 1: Avanço do cultivo de culturas temporárias em área de contato/transição para o arenito com cobertura de argissolos, distribuídos ao longo, principalmente, de média e baixa vertente.

Situação 2: Expansão de monoculturas de cultivo temporário nos limites do basalto sobre áreas de ocorrência de gleissolos e neossolos litólicos, como constatado nas manchas que identificam grau forte de fragilidade, localizadas a oeste e sudeste do município. E, em situação pontual, ainda mais acentuado em pequena área no extremo sul do município com dissecação mais elevada do relevo (8 a $20 \%)$.

\section{CONSIDERAÇÕES FINAIS}

A abordagem geossistêmica da paisagem, com base no método de Ross $(1994 ; 2012)$ de delimitação das unidades de instabilidades potenciais e emergentes e 0 aporte das geotecnologias, se mostrou eficaz e possibilitou atingir os objetivos a que este estudo se propôs - o reconhecimento e detalhamento das fragilidades ambientais - potenciais e emergentes - do município de Guaíra-PR.

Ficou evidente que a hipótese sobre a fragilidade inerente às áreas de rochas sedimentares, juntamente com os solos oriundos dessas, configuram-se em maior grau de instabilidade e fragilidade na paisagem, se confirmou após os resultados finais obtidos na análise das relações existentes entre as variáveis do quadro natural. Porém essa constatação é valida apenas para o quesito de fragilidade potencial. Em relação às fragilidades emergentes esse padrão se modifica, pois não foi possível estabelecer uma relação direta somente com a área de contato com o arenito para a determinação de maior grau de fragilidade.

O mapeamento das fragilidades emergentes evidencia que certas incoerências no uso da terra determinam, em porções de ambas as coberturas litológicas, caráter de maior instabilidade, tendo então como determinantes na fragilidade conferida outras variáveis do terreno, como solo e relevo, combinados com as práticas agrícolas de monocultivo temporário.

Foi possível também entender a dinâmica da paisagem a partir do estudo da relação dos elementos naturais que a constituí, reconhecendo como cada variável/variáveis determinam graus de fragilidade maiores ou menores no ambiente.

Sugere-se a partir deste estudo que se evite a expansão da área urbana em direção a área com sedimentos inconsolidados, devido ao grau de fragilidade potencial levantado, é necessário também atenção em relação às áreas que apresentaram grau forte de fragilidade emergente, onde devem ser priorizados atividades com práticas conservacionistas para estes ambientes.

\section{AGRADECIMENTOS}

Os autores agradecem à Coordenação de Aperfeiçoamento de Pessoal de Nível Superior - CAPES e à Fundação Araucária pela concessão de bolsa integral, proporcionando dedicação total à pesquisa, bem como a possibilidade de participação em eventos acadêmicos e demais atividades envolvidas neste projeto.

$\begin{array}{llllll}\text { Caminhos de Geografia } & \text { Uberlândia - MG } & \text { v. 19, n. } 68 & \text { Dez/2018 } & \text { p. 81-100 } & \text { Página } 98\end{array}$




\section{REFERÊNCIAS}

ÁGUAS PARANÁ - Instituto das Águas do Paraná. Bacias Hidrográficas. Águas Paraná. Disponível em: <http://www.aguasparana.pr.gov.br/modules/conteudo/conteudo.php?conteudo=38>. Acesso em: maio, 2013.

BADE, M. R. Definição e caracterização das unidades de paisagem das bacias hidrográficas do Paraná III (Brasil/Paraguai). Dissertação (Mestrado em Geografia) - Universidade Estadual do Oeste do Paraná. Programa de Pós-graduação em Geografia, Marechal Cândido Rondon-PR, 2014.

BALLER, L. Caracterização de Perfis Longitudinais nas Bacias Hidrográficas do Paraná III (Brasil) e Alto Paraná (Paraguai). Dissertação (Mestrado em Geografia) - Universidade Estadual do Oeste do Paraná. Programa de Pós-graduação em Geografia, Marechal Cândido Rondon-PR, 2014.

BERGAMO, E. P.; ALMEIDA, J. A. P. A importância da geomorfologia para o planejamento ambiental: um estudo do município de Fartura/SP. Anais do XV Simpósio Nacional de

Geomorfologia/Regional Conference on Geomorfology - 6 a 10 de setembro de 2006, UGB/IAG, Goiânia-GO. p. 1-11.

BERTRAND, G. Paisagem e geografia física global: esboço metodológico. RA'E GA, Curitiba-PR, n. 8, p. 141-152, 2004.

BRASIL. Estatuto da cidade: Lei n. 10.257, de 10 julho de 2001, e legislação correlata. (2 ed.). Brasília-DF: Câmara dos Deputados, Edições Câmara, 2009. 69 p.

BUENO, K. Fragilidade ambiental do município de Guaíra-Pr. Dissertação (Mestrado em Geografia) - Universidade Estadual do Oeste do Paraná. Programa de Pós-Graduação em Geografia. Marechal Cândido Rondon-Pr, 2015.

CARVALHO, S. M.; CAVICCHIOLI, M. A. B.; CUNHA, F. C. A. da. Paisagem: evolução conceitual, métodos de abordagem e categoria de análise da Geografia. Formação, Presidente Prudente-SP, n. 9, v.2, 2002. p. $309-347$.

CUNHA, J. E. da; ROCHA, A. S. da; BADE, M. R.; MARTINS, V. M. Fragilidade ambiental e planejamento urbano. In: FABRINI, J. E.; DIAS, E. dos S. (Org.). Dinâmica territorial e ambiental em espaço de fronteira. Cascavel-PR: EDUNIOESTE, 2012. p. 215 - 233.

EMBRAPA - Empresa Brasileira de Pesquisa Agropecuária. Sistema brasileiro de classificação de solos (3 ed.). Brasília-DF: Embrapa, 2013. 353 p.

FARIA, A. C. V. de; RICKLI NETO, J. Plano diretor, meio ambiente e turismo: a experiência de elaboração em Guaíra/PR. COMTUR, (s.d.). Disponível em:

<http://www.cepa.tur.br/comtursap/comtur_sap.htm>. Acesso em: junho, 2014.

FONSECA, F. P. da; CZUY, D. C. Formação Arenito Caiuá: uso, ocupação do solo e problemas ambientais na região noroeste do Paraná. Anais do III Simpósio Nacional de Geografia Agrária/II Simpósio Internacional de Geografia Agrária. 11 a 15 de novembro de 2005, UNESP, Presidente Prudente-SP.

GREGORY, Valdir. Os eurobrasileiros e o espaço colonial: migração no oeste do Paraná, (19401970). Cascavel: Edunioeste, 2002, 266 p.

IAPAR - Fundação Instituto Agronômico do Paraná. Cartas climáticas básicas do Estado do Paraná, Curitiba-PR, 1994. 49p.

IBGE - Instituto Brasileiro de Geografia e Estatística. Contagem Populacional. Disponível em: < http://www.ibge.gov.br/cidadesat/topwindow.htm?1> Acesso em: maio, 2013.

IPARDES - Instituto Paranaense de Desenvolvimento Econômico e Social. Caderno estatístico Município de Guaíra. Dezembro, 2013. 31 p.

ITCG - Instituto de Terras, Cartografia e Geociências do Estado do Paraná. Dados e informações geoespaciais temáticos. ITCG-PR. Disponível em:

$<$ http://www.itcg.pr.gov.br/modules/faq/category.php?categoryid=8>. Acesso em: julho, 2013.

MAACK, R. Geografia física do Estado do Paraná. 3. Ed. Curitiba-PR: Imprensa Oficial, UFPR. 2002, 350p. 
METZGER, J. P. O que é ecologia de paisagens? Biota Neotropica, v. 1, n. 1/2, Campinas-SP, 2001. p. 1-9.

MINEROPAR - Minerais do Paraná. Atlas geológico do Estado do Paraná. Curitiba-PR, 2001. 116 p.

MINEROPAR - Minerais do Paraná. Atlas geomorfológico do Estado do Paraná. Curitiba-PR, 2006. $63 \mathrm{p}$.

NÓBREGA, M. T. de; CUNHA, J. E. da. A paisagem, os solos e a suscetibilidade à erosão. Espaço Plural, no 25, Marechal Cândido Rondon-PR: UNIOESTE, 2011. p. 63-72.

NÓBREGA, M. T. de; SERRA, E. Noroeste do Paraná: a dinâmica da paisagem rural nas zonas de contato arenito-basalto. Terr@ Plural, v. 3, n. 2, Ponta Grossa-PR, jul-dez/2009. p. 197-213.

ROSS, J. L. S. Análise Empírica da Fragilidade dos Ambientes Naturais e Antropizados. Revista do Departamento de Geografia, n. 8, São Paulo-SP: FFLCH/USP, 1994.

ROSS, J. L. S. Geomorfologia: ambiente e planejamento. (9 Ed.). São Paulo-SP: Contexto, 2012. 89 p.

SCHEIBE, L. F. O município como geossistema: uma visão integradora. Geosul, Florianópolis-SC, v. 12, n. 23, jan/jun. 1997. p. $46-55$.

SEMA - Secretaria de Estado do Meio Ambiente e Recursos Hídricos (Paraná). Bacias

Hidrográficas do Paraná: Série Histórica. Curitiba-PR: SEMA, 2010. (p. 8-9; 131-138).

SOTCHAVA, V. B. Estudo de Geossistemas. Métodos em Questão, № 16. São Paulo: IG, USP, 1977. p. $1-49$.

SOUZA, E.B.C. de; SILVA, J.F.M. da. A (re)organização do espaço em Guaíra após o fim das sete quedas. RA'E GA, Curitiba-PR, n. 14, p. 85-95, 2007.

TRICART, J. Classificação ecodinâmica dos meios ambientes. In: Ecodinâmica. Rio de Janeiro-RJ: IBGE/SUPREN. 1977. 91p.

Recebido em: 26/10/2017

Aceito para publicação em: 03/09/2018 